\title{
Effect of vitamin D3 Supplementation on Thyroid Hormones and Deiodinase 2 Expression in Streptozotocin-induced Diabetic Rats
}

\author{
Zienab Alrefaie \\ Physiology Department, Faculty of Medicine, Cairo University
}

\begin{abstract}
Aim: Effect of vitamin D supplementation on peripheral conversion of T4 into T3 in diabetic rats has not been previously investigated. The present study aimed to assess the effect of vitamin D3 administration on deiodinase 2 (D2) expression in diabetic rats. Methods: Thirty male Wistar rats (200-250 g) were included into; control, diabetic and diabetic supplemented with vitamin D3 groups. Diabetes was induced by single intraperitoneal injection of streptozotocin $45 \mathrm{mg} / \mathrm{kg}$ in citrate buffer. Vitamin D3 was administered orally in a dose of $500 \mathrm{IU} / \mathrm{kg} /$ day in corn oil for 10 weeks. Serum levels of free T4, free T3 and TSH were measured. Tissue homogenates from liver, kidney, muscle, femur bone, heart and brain were obtained and assessed for expression of D2 mRNA. Results: Diabetic rats demonstrated significant increase in free T4 and significant decrease in free T3 together with non significant increase in TSH level compared to control rats. However the changes in thyroid profile were ameliorated by vitamin D3 administration to diabetic rats. D2 $\mathrm{mRNA}$ expression was significantly reduced in all tissue homogenates obtained from diabetic rats compared to control rats. Vitamin D3 treated diabetic rats showed significantly enhanced D2 $m R N A$ expression in liver and brain homogenates, while in remaining tissues; the increase in D2 mRNA did not reach significance. Conclusion: Diabetes mellitus inhibited peripheral conversion of T4 into T3 secondary to reduction in the expression of D2 in almost all body tissues. Vitamin D3 administration to diabetic rats greatly corrected the alterations in thyroid profile and D2 expression. The present results point to the possible beneficial role of vitamin D3 against the subclinical hypothyroid state that could associate diabetes mellitus.
\end{abstract}

Key words: diabetes mellitus, vitamin D3, thyroid hormones, deiodinase 2

\section{INTRODUCTION}

Uncontrolled diabetes mellitus was found to be associated with altered function of thyroid gland, this condition has been characterized as "euthyroid sick syndrome"[1].

Abnormalities in thyroid hormone levels seen in rats rendered diabetic included; decreased thyroxin
(T4), triiodothyronin (T3) and increased reverse $\mathrm{T} 3$ while thyroid stimulating hormone (TSH) was found to be low or normal ${ }^{[2]}$. However little is known about the effects of diabetes mellitus on peripheral conversion of $\mathrm{T} 4$ into active $\mathrm{T} 3$.

$80-90 \%$ of the circulating T3 is derived from the $\mathrm{T} 4$ intracellularly. The conversion of $\mathrm{T} 4$ to $\mathrm{T} 3$ is 
catalyzed by type 1 (D1) and type 2 (D2) deiodinases via outer-ring deiodination. ${ }^{[3]}$

D2 is considered the main T4activating enzyme and the key enzyme for $\mathrm{T} 3$ generation as stated by Dora et al. ${ }^{[4]}$

Significant controversy has been raised recently regarding the effects of vitamin $\mathrm{D}$ on nonskeletal tissues. Vitamin D receptors were found to be expressed in almost all cells of the body, in addition many observations supported the relationship of serum 25-hydroxyvitamin $\mathrm{D}$ to many diseases and disorders. Interest in vitamin $\mathrm{D}$ as a therapeutic modality for the prevention of nonskeletal diseases has much increased ${ }^{[5,6]}$.

In fact, the effect of vitamin $D$ supplementation on thyroid status and peripheral deiodination of $\mathrm{T} 4$ into $\mathrm{T} 3$ in diabetic rats was not worked out previously.

\section{Aim}

The present study was designed to assess the effect of vitamin D3 supplementation on diabetes-induced changes in free T4, free T3 and TSH levels and D 2 mRNA expression of streptozotocin-induced diabetic rats

\section{METHODS}

\section{Animals}

Thirty adult male Wistar rats weighing (200-250 g) were included in the present study. They were obtained and maintained at the animal house, Kasr Alini Faculty of Medicine, Cairo University. Animals were kept at room temperature under $12 \mathrm{~h}$ light/ dark cycle. They were allowed free access to rat chaw and water.

\section{Chemicals}

Streptozotocin was obtained from MB Biomedicals LLA, California, USA. While vitamin D3 was obtained from Sigma-Aldrich Co., St. Louis, USA.

\section{Experimental design}

Twenty rats were made diabetic by single intraperitoneal injection of streptozotocin (stz) $(45 \mathrm{mg} / \mathrm{kg}$ body weight) in citrate buffer $(\mathrm{pH} 4.5)^{[7]}$. Diabetes was confirmed by blood glucose levels above $250 \mathrm{mg} / \mathrm{dl} 72$ hours following injection. The remaining 10 rats received intraperitoneal equivalent volume of citrate buffer and accounted for the control group.

Diabetic animals were classified into; diabetic group, and diabetic group supplemented with vitamin D3; rats were administered orally vitamin D3 in a dose of $500 \mathrm{IU} / \mathrm{kg} /$ day in corn oil for 10 weeks ${ }^{[8]}$.

At the end of the experiment after an overnight fast, blood samples were collected through retro orbital rout and sera were separated and used for measurement of freeT4, free $\mathrm{T} 3$ and TSH levels.

Then animals were sacrificed under diethyl ether anesthesia, tissue samples from liver, kidney, muscle, femur bone, heart and brain were dissected and kept at -80 until measurement of D2 mRNA expression.

\section{Biochemical measurements}

Free T4 and T3 were measured using electrochemiluminescence assay technique (Immuno Diagnostics Inc. USA) while TSH was measured using Cusabio rat ultrasensitive TSH ELIZA kit (U-TSH) (Wuhan Huamei Biotech, Inc. China). 


\section{Detection of D2 gene by Real-time RT-PCR}

1-Ribonucleic acid (RNA) extraction and complementary deoxyribonucleic acid (cDNA) synthesis.

Total RNA was isolated from different tissue homogenates using trizol reagent TM (Invitrogen, Carlsbad, CA) according to the manufacturer's protocol

The RNA sample was dissolved in RNase-free water and quantified spectrophotometrically. The integrity of the RNA was studied by gel electrophoresis on a $1 \%$ agarose gel, containing ethidium bromide. Firststrand cDNA synthesis was performed with the Superscript Choice System (Life Technologies, Breda, the Netherlands) by mixing $2 \mu \mathrm{g}$ total RNA with $0.5 \mu \mathrm{g}$ of oligo (dT)12-18 primer in a total volume of $12 \mu \mathrm{L}$. After the mixture was heated at $70^{\circ} \mathrm{C}$ for $10 \mathrm{~min}$, a solution containing 50 $\mathrm{mmol} / \mathrm{L}$ Tris $\cdot \mathrm{HCl} \quad(\mathrm{pH}$ 8.3), 75 $\mathrm{mmol} / \mathrm{L} \mathrm{KCl}, 3 \mathrm{mmol} / \mathrm{L} \mathrm{MgCl} 2,10$ $\mathrm{mmol} / \mathrm{L}$ DTT, $0.5 \mathrm{mmol} / \mathrm{L}$ dNTPs, 0.5 $\mu \mathrm{L}$ RNase inhibitor, and $200 \mathrm{U}$ Superscript Reverse Transcriptase was added, resulting in a total volume of $20.5 \mu \mathrm{L}$. This mixture was incubated at $42^{\circ} \mathrm{C}$ for $1 \mathrm{~h}$ and then stored at $80^{\circ} \mathrm{C}$ until further use.

2- Real time quantitative PCR

For real time quantitative PCR, 1 $\mu \mathrm{L}$ of first-strand cDNA diluted 1:10 in RNase-free water was used in a total volume of $25 \mu \mathrm{L}$, containing 12.5 $\mu \mathrm{L} 2 \mathrm{x}$ SYBR Green PCR Master Mix (Applied Biosystems, Foster City, CA, USA) and $200 \mathrm{ng}$ of each primer.

Primers, designed with the Primer Express software package (Applied Biosystems), for Type 2 iodothyronine deiodinase gene (forward 5'- 5' GGCTGACTTCCTGTTG-

3'(Reverse 5'CACATCGGTCCTCTTGGTTCC 3') $\beta$-actin primers (forward 5'TGTTGTCCCTGTATGCCTCT-3', reverse $5^{\prime}-$ TAATGTCACGCACGATTTCC-3'). PCR reactions, consisting of $95^{\circ} \mathrm{C}$ for $10 \mathrm{~min}(1 \mathrm{cycle}), 94^{\circ} \mathrm{C}$ for $15 \mathrm{~s}$, and $60^{\circ} \mathrm{Cfor} 1 \mathrm{~min}$ (40 cycles), were performed on an ABI Prism 7900 HT Fast Real Time PCR system (Applied Biosystems). Data were analyzed with the ABI Prism 7900sequence detection system software (version 2.2) and quantified with the comparative threshold cycle method with beta actin as a housekeeping gene reference ${ }^{[9]}$.

\section{Statistical Analysis}

Data were statistically evaluated with SPSS for windows package version 20 (SPSS Inc., Chicago, IL, USA). Results are expressed as the Mean \pm SD. One way analysis of variance (ANOVA) test was used to compare between groups. Significance level at $\mathrm{P}<0.05$ was considered to indicate statistical significance.

\section{RESULTS}

Results obtained in the present study revealed significant changes in the thyroid profile 10 weeks after induction of diabetes mellitus.

Diabetic rats demonstrated significant increase in free $\mathrm{T} 4$ and significant decrease in free $\mathrm{T} 3$ together with non significant increase in TSH level compared to control rats.

Vitamin D3 supplementation to diabetic rats significantly ameliorated 
the alterations in the levels of free T4, T3 and TSH which were returned towards normal (Table 1 and Figure $1)$.

Deiodinase 2 mRNA expression revealed highly significant reduction in homogenates of liver, kidney, muscle, heart and brain tissues obtained from diabetic rats compared to control rats $(\mathrm{P}<0.001)$. Femur bone homogenates demonstrated the least significant reduction in D2 mRNA expression in diabetic rats compared to control non diabetic rats $(\mathrm{P}<0.01)$.
Diabetic rats treated with vitamin D3 demonstrated significant enhancement of D2 mRNA expression in liver and brain homogenates when compared to the untreated diabetic rats. It is observed that although D2 expression was also increased in kidney, muscle, bone and heart homogenates of diabetic rats in response to vitamin D3 administration, but this increase did not reach statistical significance (Table 2 and Figures 2-3).

Table 1: Serum levels of free T4 (ng/dl), T3 (pg/ml), TSH (nIU/ml) and glucose $(\mathrm{mg} / \mathrm{dl})$ in control group, diabetic group and diabetic group treated with vitamin D3.

\begin{tabular}{|c|c|c|c|}
\hline Parameter & Control group & Diabetic group & Diabetic + vit D3 group \\
\hline Free T4 & $0.84 \pm 0.19$ & $\begin{array}{l}1.27 \pm 0.43 \\
\mathrm{P}_{1}<0.05\end{array}$ & $\begin{array}{l}0.83 \pm 0.17 \\
\mathrm{P}_{1}: \mathrm{NS} \\
\mathrm{P}_{2}<0.01\end{array}$ \\
\hline Free T3 & $3.83 \pm 0.25$ & $\begin{array}{l}2.05 \pm 0.5 \\
\mathrm{P}_{1}<0.001\end{array}$ & $\begin{array}{l}2.87 \pm 0.55 \\
\mathrm{P}_{1}<0.01 \\
\mathrm{P}_{2}<0.01\end{array}$ \\
\hline TSH & $53.55 \pm 12.67$ & $\begin{array}{l}70.15 \pm 19.2 \\
\mathrm{P}_{1}: \mathrm{NS}\end{array}$ & $\begin{array}{l}56.91 \pm 18.63 \\
\mathrm{P}_{1}: \mathrm{NS} \\
\mathrm{P}_{2}: \mathrm{NS} \\
\end{array}$ \\
\hline Glucose & $86.88 \pm 10.96$ & $\begin{array}{l}271.87 \pm 52.1 \\
P_{1}<0.001\end{array}$ & $\begin{array}{l}193 \pm 16.71 \\
\mathrm{P}_{1}<0.001 \\
\mathrm{P}_{2}<0.001\end{array}$ \\
\hline
\end{tabular}

$\mathrm{P}_{1}$ : Significant when compared to control group

$\mathrm{P}_{2}$ : Significant when compared to diabetic group

NS: Non significant 
Table 2: Deiodinase 2 (D2) mRNA expression in tissue homogenates from liver, kidney, muscle, femur, heart and brain of control group, diabetic group and diabetic group treated with vitamin D3.

\begin{tabular}{|c|c|c|c|}
\hline Parameter & Control group & Diabetic group & Diabetic + vit D3 group \\
\hline D2 Liver & $1.77 \pm 0.33$ & $\begin{array}{l}0.2 \pm 0.12 \\
\mathrm{P}_{1}<0.001\end{array}$ & $\begin{array}{l}0.6 \pm 0.24 \\
P_{1}<0.001 \\
P_{2}<0.01\end{array}$ \\
\hline D2 Kidney & $1.51 \pm 0.42$ & $\begin{array}{l}0.32 \pm 0.22 \\
\mathrm{P}_{1}<0.001\end{array}$ & $\begin{array}{l}0.58 \pm 0.26 \\
\mathrm{P}_{1}<0.001 \\
\mathrm{P}_{2}: \mathrm{NS}\end{array}$ \\
\hline D2 Muscle & $0.98 \pm 0.04$ & $\begin{array}{l}0.46 \pm 0.12 \\
P_{1}<0.001\end{array}$ & $\begin{array}{l}0.52 \pm 0.21 \\
\mathrm{P}_{1}<0.01 \\
\mathrm{P}_{2}: \mathrm{NS}\end{array}$ \\
\hline D2 Bone & $1.28 \pm 0.54$ & $\begin{array}{l}0.44 \pm 0.23 \\
\mathrm{P}_{1}<0.01\end{array}$ & $\begin{array}{l}0.6 \pm 0.42 \\
\mathrm{P}_{1}<0.05 \\
\mathrm{P}_{2}: \mathrm{NS}\end{array}$ \\
\hline D2 Heart & $1.47 \pm 0.25$ & $\begin{array}{l}0.61 \pm 0.23 \\
\mathrm{P}_{1}<0.001\end{array}$ & $\begin{array}{l}0.79 \pm 0.2 \\
\mathrm{P}_{1}<0.01 \\
\mathrm{P}_{2}: \mathrm{NS}\end{array}$ \\
\hline D2 Brain & $1.94 \pm 0.21$ & $\begin{array}{l}0.52 \pm 0.26 \\
P_{1}<0.001\end{array}$ & $\begin{array}{l}1.05 \pm 0.22 \\
\mathrm{P}_{1}<0.001 \\
\mathrm{P}_{2}<0.01\end{array}$ \\
\hline
\end{tabular}

$\mathrm{P}_{1}$ : Significant when compared to control group

$\mathrm{P}_{2}$ : Significant when compared to diabetic group

NS: Non significant

Figure 1: Serum levels of free T4 (ng/dl), T3 (pg/ml), TSH (nIU/ml) and glucose $(\mathrm{mg} / \mathrm{dl})$ in control group, diabetic group and diabetic group treated with vitamin D3.
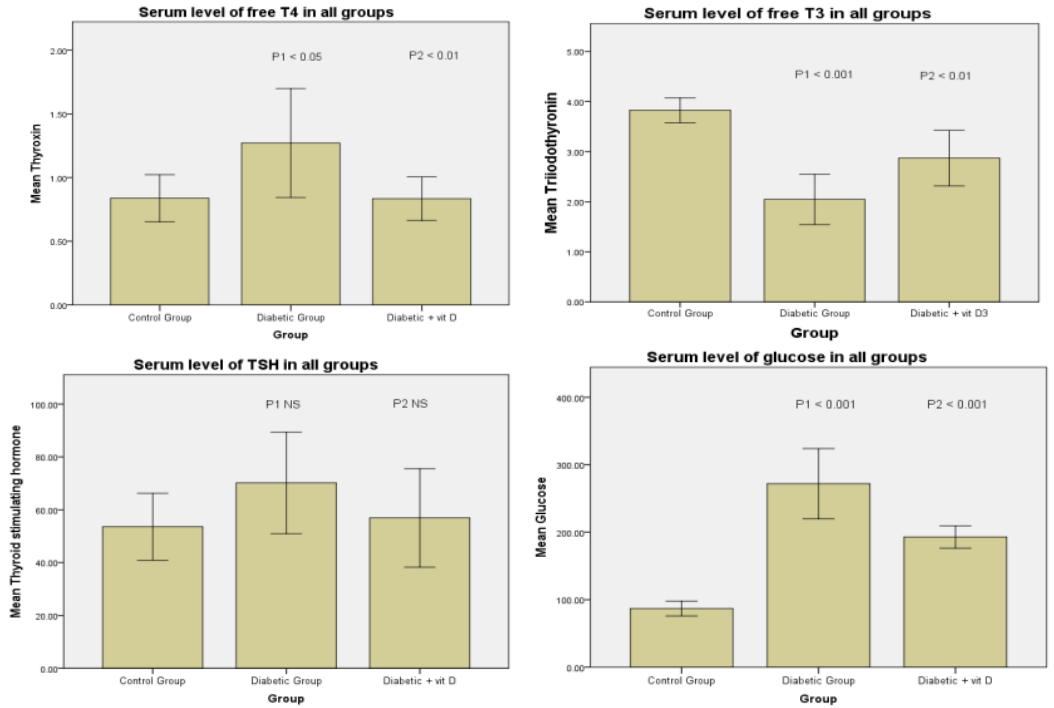

P1: Significant when compared to control group

P2: Significant when compared to diabetic group

NS: Non Significant 
Figure 2: Deiodinase 2 (D2) mRNA expression in tissue homogenates from liver, kidney, muscle, and femur bone of control group, diabetic group and diabetic group treated with vitamin D3.
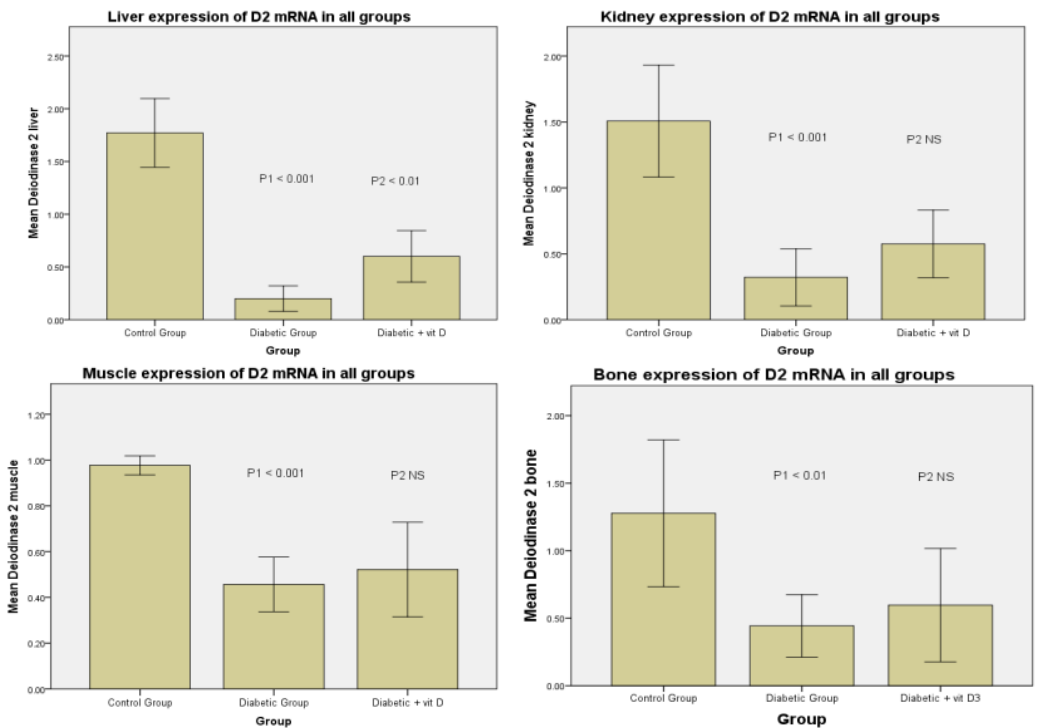

P1: Significant when compared to control group

P2: Significant when compared to diabetic group

NS: Non Significant

Figure 3: Deiodinase 2 (D2) mRNA expression in tissue homogenates from heart and brain of control group, diabetic group and diabetic group treated with vitamin D3.
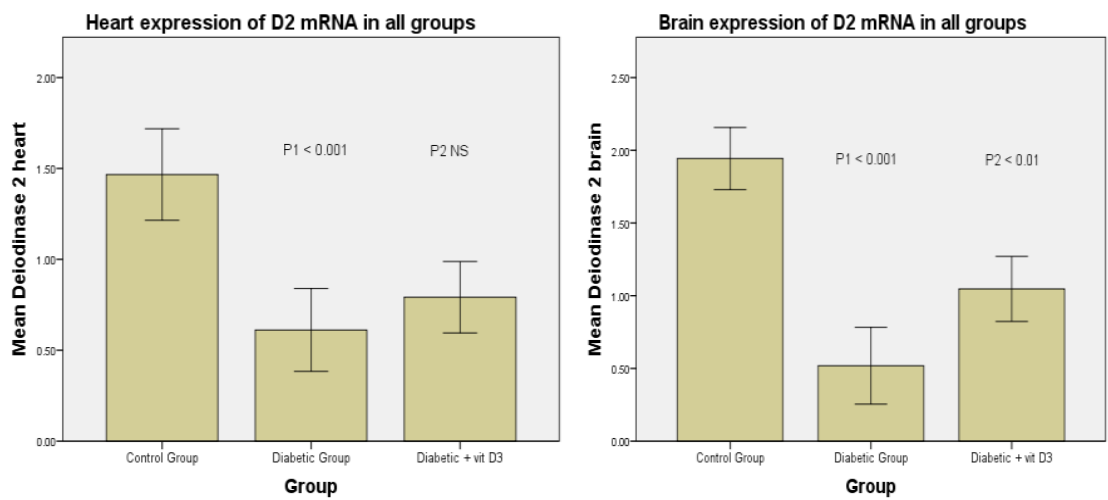

P1: Significant when compared to control group

P2: Significant when compared to diabetic group

NS: Non Significant 


\section{DISCUSSION}

Findings of the present work demonstrated that stz-induced diabetes mellitus for 10 weeks significantly elevated free $\mathrm{T} 4$ and significantly reduced free $\mathrm{T} 3$ with significant reduction in D2 mRNA in almost all body tissues. Supplementation of diabetic rats with the active form of vitamin $D$, produced beneficial effects as it returned the levels of thyroid hormones towards normal and enhanced the expression of D2 in all tissues assessed specially the liver and brain.

According to most updated works, the present study is the first to investigate the effect of vitamin D3 administration on peripheral conversion of $\mathrm{T} 4$ into active $\mathrm{T} 3$ in many body tissues in diabetic rats.

Diabetes mellitus is one of the most common clinical problems. It could result in many complications including thyroid gland dysfunction. Saravanan and Ponnurugan ${ }^{[10]}$ observed significant decrease in T3, $\mathrm{T} 4$ and TSH levels in stz-induced diabetic rats 45 days after induction of diabetes. The authors explained their observation that stz-induced liver damage resulted into two problems; first decreased T3 production in the liver, second decreased production of thyroid binding proteins leading to decrease in $\mathrm{T} 3$ and $\mathrm{T} 4$ levels.

The present results apparently invalidate the explanation of Saravanan and Ponnurugan, as D2 was decreased in many body tissues other than the liver indicating decreased $\mathrm{T} 3$ production all over the body and not only in the liver. In addition, the present work assessed the free levels of T4 and T3 which is more accurate than measurement of total levels that could be affected by thyroid binding proteins.

Previously, Parmar and $\mathrm{Kar}^{[11]}$, induced diabetes by feeding rats atherogenic diet for 14 days. The authors demonstrated reduction in total T3, T4 and hepatic D1 in atherogenic diet-induced diabetic animals.

Although the great difference in the experimental design between present work and work of Parmar and Kar, but their findings point to decreased thyroid function in diabetic models.

Similarly, Santos et al. ${ }^{[12]}$ pointed to the prevalence of thyroid disorders especially subclinical hypothyroidism in diabetic rats agreeing with the present findings.

In accord with the present results and in human patients, Chubb et al. ${ }^{[13]}$ stated that subclinical hypothyroidism is common among type 2 diabetic patients. Also high prevalence of thyroid dysfunction in thyroid ultra sound scanning was found in young patients with type 1 diabetes mellitus ${ }^{[14]}$.

Results of diabetic rats in the present work showed non significant elevation of TSH, this further supports the possibility of development of subclinical hypothyroid state especially with decreased deiodination of T4 into T3 in many tissues. This finding also suggests that the pituitary feed-back might greatly depend on the $\mathrm{T} 3$ formed through action of D2 in the brain.

In support to this hypothesis, it was stated earlier that in the brain 
$80 \%$ of $\mathrm{T} 3$ is formed locally from $\mathrm{T} 4$ through activity of $\mathrm{D} 2^{[15]}$.

Supplementation of vitamin D3 has been assessed for possible beneficial effects in many clinical entities.

The present work could be the first to assess effect of vitamin D3 supplementation on D2 expression in diabetic rats in almost all body tissues.

Relation of vitamin D to Hashimoto's thyroiditis has been much investigated. Very little work in the literature investigated the relation of vitamin $\mathrm{D}$ to other thyroid dysfunction or illnesses.

Recently, Chailurkit et al. ${ }^{[16]}$, in their population-based study demonstrated that high vitamin D status was associated with low circulating TSH. This was exactly observed in the present study in the diabetic group treated with vitamin D3 in which TSH levels were decreased towards normal in comparison with the untreated diabetic group.

Previously Gouveia et al. ${ }^{[17]}$, revealed that treatment of bone extracts from mice skeleton with vitamin D3 increased D2 activity by 2-3 fold as early as 24 hours. Their observation highlights the beneficial effect of vitamin D3 on bone tissue D2 and supports the present findings.

In conclusion, the present data revealed that diabetes mellitus impaired thyroid hormone status and compromised peripheral conversion of T4 into T3 due to inhibition of D2 mRNA expression. For the first time, the present work provides evidence that vitamin D3 supplementation ameliorated the decline in peripheral production of $\mathrm{T} 3$ in diabetic rats and corrected the alterations in the level of thyroid hormones.

\section{REFERENCES}

1- Tabata S, Toyoda N, Nishkawa $\mathrm{M}$, Yonemoto $\mathrm{T}$, Gondou A, Ogawa Y et al. 1999. Effect of streptozotocin-induced diabetes mellitus on type 1 deiodinase in inherited D1 deficient mice. Endocrine J 46(4): 497-504.

2- Tabata S, Nishkawa M, Toyoda N, Yonemoto T, Ogawa Y, Inada M. 1999. Effect of triiodothyronin administration on reduced expression of type 1 iodothronin mRNA in streptozotocin-induced diabetic rats. Endocrine J 46(3): 367-374.

3- St Germain DL, Galton VA, Hernandez A. 2009 Minireview: Defining the roles of the iodothyronine deiodinases: current concepts and challenges. Endocrinology 150(3):1097-107.

4- Dora JM, Machado WE, Rheinheimer J, Crispim D, Maia AL. 2010 Association of the type 2 deiodinase Thr92Ala polymorphism with type 2 diabetes: case-control study and meta-analysis. Eur J Endocrinol. 163(3):427-34

5- Christakos S, DeLuca HF 2011 Minireview: vitamin D, is there a role in extraskeletal health? Endocrinology 152: 2930-2936

6- Rosen CJ, Adams JS, Bikle DD, Black DM, Demay MB, Manson JE, Murad MH, Kovacs CS. 2012 The nonskeletal effects of vitamin D: an Endocrine Society scientific statement. Endocr Rev. 33(3): 456-92. 
7- Pari L, Sankaranarayanan C. 2009 Beneficial effects of thymoquinone on hepatic key enzymes in streptozotocininduced diabetic rats. Life Sci 85(26):830-4.

8- Salum E, Kampus P, Zilmer M, Eha J, Butlin M, Avolio AP, Põdramägi T, Arend A, Aunapuu M, Kals J. 2012 Effect of vitamin D on aortic remodeling in streptozotocininduced diabetes. Cardiovasc Diabetol. 11:58-62.

9- Pfaffl MW. 2001 A new mathematical model for relative quantification in real-time RTPCR. Nucleic Acids Res 29:e45.

10- Saravanan G, Ponmurugan $P$. 2012 Antidiabetic effect of Sallylcysteine: effect on thyroid hormone and circulatory antioxidant system in experimental diabetic rats. $\mathbf{J}$ Diabetes Complications 26:280 285.

11- Parmar HS, Kar A. 2007 Atherogenic diet induced diabetes mellitus: involvement of thyroid hormones. Eur J Pharmacol 570: 244-248.

12- Santos MC, Louzada RA, Souza EC, Fortunato RS, Vasconcelos AL, Souza KL, Castro JP, Carvalho DP, Ferreira AC. 2013 Diabetes mellitus increases reactive oxygen species production in the thyroid of male rats. Endocrinology 154(3):136172.
13- Chubb SA, Davis WA, Inman Z, Davis TM. 2005 Prevalence and progression of subclinical hypothyroidism in women with type 2 diabetes: the Fremantle Diabetes Study. Clin Endocrinol 62(4):480-6.

14- Hansen D, Bennedbaek FN, Høier-Madsen M, Hegedüs L, Jacobsen BB. 2003 A prospective study of thyroid function, morphology and autoimmunity in young patients with type 1 diabetes. Eur J Endocrinol. 148(2):245-51.

15- Guadano-Ferraz A, Escamez MJ, Rausell E, Bernal J. 1999 Expression of type 2 iodothyronin deiodinase in hypothyroid rat brain indicates an important role of thyroid hormone in the development of specific primary sensory systems. J Neurosci 19(9):3430-9

16- Chailurkit LO, Aekplakorn W, Ongphiphadhanakul B. 2013 High vitamin D status in younger individuals is associated with low circulating thyrotrophin. Thyroid 23(1):25-30.

17- Gouveia $\mathrm{CH}$, Christoffolete MA, Zaitune CR, Dora JM, Harney JW, Maia AL, Bianco AC. 2005 Type 2 iodothyronine selenodeiodinase is expressed throughout the mouse skeleton and in the MC3T3-E1 mouse osteoplastic cell line during differentiation. Endocrinology 146(1):195-200. 


\section{المستخلص العربى - (المى}

الهدف :لم يتم التحقق من أثر فيتامين د على تحويل هرمون T4 إلى T3 في أنسجة الجسم المختلفة في الفئران

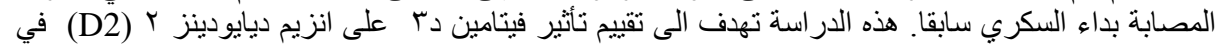
الجرذان المصابة بداء السكري.

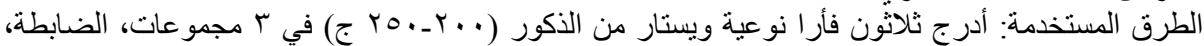

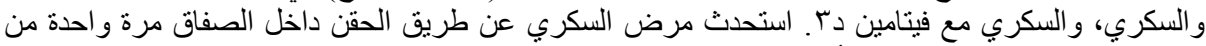

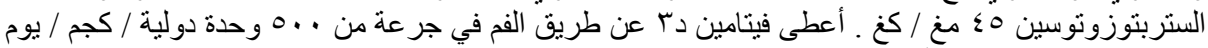

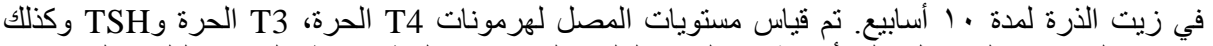

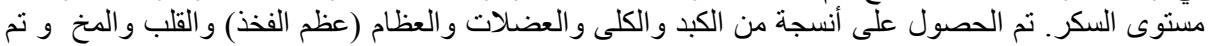

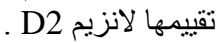

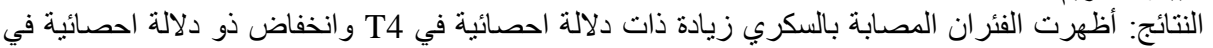

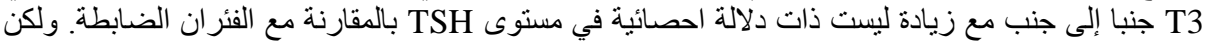

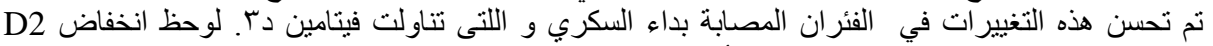

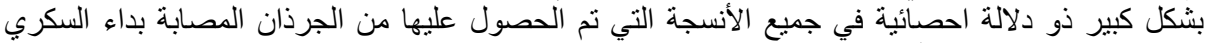

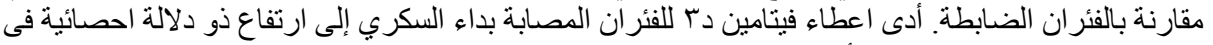

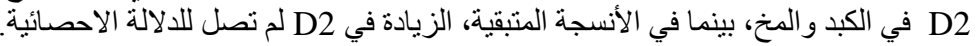

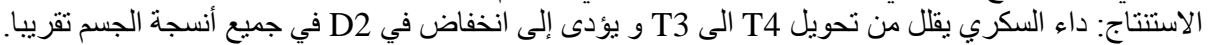

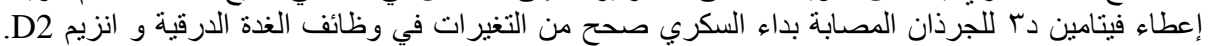

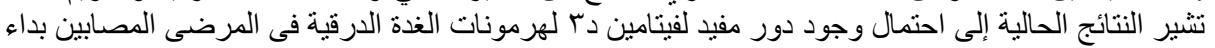
السكري. 